\title{
PENENTUAN FREKUENSI DAN TINGKAT TEKANAN BUNYI EFEKTIF UNTUK MENGUSIR BURUNG DI KAWASAN BANDARA AHMAD YANI SEMARANG
}

\author{
Determination of The Effective Frequency and Sound Pressure Level \\ to Repel Birds at Ahmad Yani Airport Semarang
}

\author{
Maharani Ratna Palupi dan Budhy Basuki \\ Pusat Riset dan Pengembangan Sumber Daya Manusia, Badan Standardisasi Nasional \\ Kompleks Puspiptek Gedung 430 Setu Tangerang Selatan, Banten, Indonesia \\ Email: maharani@bsn.go.id
}

\begin{abstract}
Abstrak
Teknik pengendalian gangguan burung di bandar udara dapat dilakukan salah satunya dengan teknik auditory metode akustik memanfaatkan frekuensi sensitif pendengaran burung. Frekuensi sensitif pendengaran burung ini berbeda pada tiap spesies burung, berbeda pula pada jenis burung yang sama namun berada pada habitat yang berbeda. Sehingga untuk mengendalikan gangguan burung di bandar udara internasional Ahmad Yani Semarang perlu dilakukan survey dan pengukuran lapangan mengenai jenis-jenis burung, frekuensi dan tingkat tekanan bunyi baik yang dikeluarkan burung maupun dari deru pesawat yang sedang lepas landas dan mendarat di landasan pacu. Hasil survey dan pengukuran lapangan menjadi dasar pemilihan frekuensi dan tingkat tekanan bunyi untuk mengusir burung di kawasan aerodrome bandar udara internasional Ahmad Yani Semarang. Dari hasil survey dan pengukuran lapangan menunjukkan bahwa burung yang banyak ditemukan di area aerodrome bandar udara internasional Ahmad Yani Semarang adalah burung Blekok Sawah (Ardeola speciose), frekuensi burung yaitu 800 $\mathrm{Hz}$ sampai $5000 \mathrm{~Hz}$ yang tidak beririsan sama sekali dengan frekuensi pesawat terbang yaitu sekitar $63 \mathrm{~Hz}$ sampai $250 \mathrm{~Hz}$. Dari dua kali percobaan pengusiran burung, di area sarang burung dan area aerodrome, signal generator diatur automatic frequency sweeping secara berulang mulai dari frekuensi $800 \mathrm{~Hz}$ sampai dengan frekuensi $5 \mathrm{kHz}$ dengan durasi sweeping minimal 2 detik, dengan tingkat tekanan bunyi $85 \mathrm{~dB}$ pada jarak 1 meter di depan speaker dapat diamati bahwa burung-burung merespon dengan terbang menjauhi sumber bunyi dan sebagian besar tidak kembali.
\end{abstract}

Kata kunci: bird strike, frekuensi, tingkat tekanan bunyi, Bandar Udara

\begin{abstract}
One of the bird deterrent techniques at the airports is the auditory method by using the sensitive frequencies of bird hearing. These frequencies are different in each species of birds, and also vary in different habitats. So that, to control the bird disturbances at Ahmad Yani Semarang International Airport, it is necessary to conduct field surveys and measurements of the birds - both the species and the frequencies of hearing -, and the noise of airplanes that take-off and landed on runway. The result of this survey and measurement will be used to determine the frequencies and sound pressure level to beat back the birds from the aerodrome area. The results show that Blekok Sawah (Ardeola speciose) is the dominating birds in the aerodrome, the frequencies of the birds are $800 \mathrm{~Hz}$ to $5000 \mathrm{~Hz}$ that no intersect with the airplanes frequencies (at around $63 \mathrm{~Hz}$ to $250 \mathrm{~Hz}$ ). From the two experiments to repel birds, at the bird's nest and aerodrome, the signal generator was set to automatic frequency sweeping from $800 \mathrm{~Hz}$ to $5000 \mathrm{~Hz}$ with 2 seconds sweeping duration. The sound pressure level was set to $85 \mathrm{~dB}$ at $1 \mathrm{~m}$ in front of speaker. It was observed that the birds flew away avoiding the sound source and most of them were not return back.
\end{abstract}

Keywords: bird strike, frequency, sound pressure level, airport

\section{PENDAHULUAN}

Bird strike atau gangguan burung adalah dampak bersentuhannya dua material berkecepatan tinggi yang memiliki perbedaan sifat sangat besar, dimana burung bersifat lunak bersentuhan dengan badan pesawat yang bersifat kaku, sehingga menghasilkan perilaku material nonlinear, laju regangan tinggi, dan deformasi yang sangat besar
(Hedayati, R dan Sadighi, M. 2015). Gangguan burung pada saat proses penerbangan dapat terjadi baik secara berkelompok maupun tunggal, dan pertama kali diidentifikasi terjadi pada tahun 1908 pada penerbangan Wright Brothers. Kejadian gangguan burung dilaporkan meningkat setiap tahunnya utamanya disebabkan oleh program pelestarian dan perlindungan lingkungan hidup yang semakin ketat sehingga mendukung pertumbuhan populasi jenis-jenis burung. 
Gangguan burung dapat terjadi pada ketinggian yang beragam dan $41 \%$ dari kejadian gangguan burung di Amerika terjadi pada saat proses lepas landas atau pendaratan (Martono, A. 2007).

Dokumen International Civil Aviation Organization (ICAO) 9137-AN bagian 3, tentang Pengendalian dan Pengurangan Burung di Landas Pacu Bandar Udara mensyaratkan pencegahan gangguan burung di bandar udara harus dipenuhi untuk keselamatan penerbangan. (Cardoso, S.H. 2001). Keselamatan penerbangan merupakan hal yang diatur dalam Undang-Undang Republik Indonesia No. 1 tahun 2009 tentang Penerbangan, dan Prosedur pelaporan Serangan burung di bandar udara dan sekitarnya diatur dalam Peraturan Direktur Jenderal Perhubungan Udara No. KP.468 tahun 2011.

Teknik pengendalian gangguan burung di bandar udara dapat dikategorikan secara auditory, visual, kimia, exclusion, modifikasi habitat, dan pemusnahan (Bishop, J. 2003). Secara auditory biasanya dilakukan menggunakan metode akustik dengan merekam suara hewan predator dan memancarkan suara hewan predator melalui pengeras suara di bandar udara. Teknik lainnya adalah dengan menggunakan burung predator yang dikendalikan pawangnya. Selain memperkecil gangguan burung dengan Teknik pengendalian di atas, Royal Netherlands Airforce mendeteksi jalur pergerakan burungburung dengan menggunakan Radar Observation of Bird Intensity (ROBIN). Dengan menggunakan ROBIN, pilot dapat menghindari jalur migrasi burung-burung. (Pusat Penelitian Metrologi, 2016)

Awal penelitian tentang alternatif metode akustik untuk pengendalian gangguan burung di bandar udara di Indonesia dilakukan oleh Husein A. Akil dan tim pada 2003. Metode akustik yang dikembangkan adalah dengan menggunakan frekuensi komunikasi burung yang diperkirakan juga merupakan frekuensi sensitif pendengaran burung. Frekuensi sensitif pendengaran burung ini kemudian dipancarkan melalui pengeras suara ke sekumpulan burung (Akil, H.A. 2003). Seiring dengan waktu, ditemukan bahwa frekuensi sensitif pendengaran burung berbeda untuk setiap jenis burung. Frekuensi sensitif pendengaran burung juga berbeda untuk satu jenis burung yang sama namun berbeda habitat. Sehingga frekuensi yang diperlukan untuk mengusir burung akan berbeda di setiap bandar udara, bergantung pada jenis burung yang mendominasi dan lokasi di mana bandar udara itu berada.

Menjelang akhir tahun 2016, PT. Angkasa Pura I selaku pengelola bandar udara internasional Ahmad Yani Semarang mengajukan permintaan kajian bird strike kepada Pusat Penelitian Metrologi LIPI. Permintaan ini didasarkan pada kenyataan meningkatnya populasi burung di kawasan aerodrome yang berpotensi terjadinya bird strike. Mengingat perbedaan lokasi dan jenis burung mempengaruhi frekuensi bunyi yang diperlukan dalam pengendalian gangguan burung, maka penentuan frekuensi bunyi dan tingkat tekanan bunyi yang diperlukan di kawasan aerodrome bandar udara internasional Ahmad Yani Semarang menjadi pokok bahasan dalam tulisan ini

\section{TINJAUAN PUSTAKA}

Fenomena akustik terjadi apabila ada interaksi antara sumber bunyi, media penghantar gelombang bunyi dan penerima bunyi. Deru pesawat saat lepas landas maupun mendarat dan kicauan burung merupakan sumber bunyi. Udara merupakan media penghantar gelombang bunyi. Telinga manusia, telinga burung, dan alat pengukur kebisingan seperti sound level meter merupakan penerima bunyi. Wilayah pendengaran manusia disebut frekuensi audible berada di $20 \mathrm{~Hz}$ sampai 20 kHz. Kekerasan (loudness) tekanan bunyi yang paling rendah yang dapat dirasakan oleh telinga manusia disebut ambang batas dengar (threshold of hearing) sedangkan kekerasan tekanan bunyi yang paling tinggi yang dapat menyebabkan sakit atau bahkan merusak komponen indra pendengaran manusia disebut ambang sakit pendengaran (threshold of pain).

Secara umum telinga manusia sensitif pada daerah frekuensi antara $1 \mathrm{kHz}$ sampai dengan $5 \mathrm{kHz}$ dan telinga manusia menjadi kurang sensitif pada daerah frekuensi sangat rendah dan frekuensi sangat tinggi. Sebagai indera makhluk hidup, telinga manusia dan hewan apabila mendengar bunyi pada daerah pendengaran sensitif dengan tingkat kekerasan mencapai ambang sakit (threshold of pain), maka akan merasa tidak nyaman atau bahkan merasa sakit pada indera pendengaran (Akil, H.A. 2003).

Untuk manusia, terdapat nilai ambang batas durasi pajanan kebisingan yang diatur dalam Peraturan Menteri Kesehatan no 70 tahun 2016 tentang standar dan persyaratan kesehatan lingkungan kerja industri. NAB kebisingan ini didasarkan pada ambang sakit 
indera pendengaran manusia. Nilai ambang batas kebisingan dapat dilihat pada tabel 1 .

Tabel 1. NAB Kebisingan

\begin{tabular}{ccc}
\hline Satuan & $\begin{array}{c}\text { Durasi } \\
\text { pajanan } \\
\text { kebisingan } \\
\text { per Hari }\end{array}$ & $\begin{array}{c}\text { Level } \\
\text { Kebisingan } \\
\text { (dBA) }\end{array}$ \\
\hline \multirow{7}{*}{ Jam } & 24 & 80 \\
& 16 & 82 \\
& 8 & 85 \\
Menit & 4 & 88 \\
& 1 & 91 \\
& 30 & 94 \\
\hline \multirow{6}{*}{ Detik } & 15 & 97 \\
& 7,5 & 100 \\
& 3,75 & 103 \\
& 1,88 & 106 \\
& 0,94 & 112 \\
\hline & 28,12 & 115 \\
& 14,06 & 118 \\
& 7,03 & 121 \\
& 3,52 & 124 \\
& 1,76 & 127 \\
& 0,88 & 130 \\
& 0,44 & 133 \\
& 0,22 & 136 \\
& 0,11 & 139 \\
\hline
\end{tabular}

Burung berkomunikasi dengan sesamanya menggunakan bunyi yang dihasilkan burung-burung itu sendiri. Burung memiliki sensitivitas pendengaran $10 \times$ lebih sensitif dibanding manusia. Dengan menggunakan analogi bahwa burung merupakan makhluk hidup, maka ada daerah sensitif pendengaran burung yang bisa dikenakan bunyi pada tingkat tekanan bunyi tertentu akan menyentuh ambang sakit sehingga merasa tidak nyaman.

Telinga burung secara garis besar dibagi kedalam tiga bagian, yaitu telinga bagian luar, bagian tengah, dan bagian dalam. Telinga bagian luar terdiri dari pipa (ear canal) yang akan menyalurkan gelombang bunyi kepada gendang telinga (eardrum). Di belakang eardrum ada telinga bagian tengah yang terdiri dari tulang tunggal yang di sebut collumella bertugas mentransformasikan sinyal getaran menjadi pulsa listrik dan diteruskan ke telinga bagian dalam yang disebut cochlea. Telinga bagian dalam berisi cairan dan sel-sel syaraf akan menghantarkan pulsa listrik ke otak untuk diproses. Hasil pengolahan pulsa listrik oleh otak ini adalah berupa persepsi bunyi seperti keras lemah, ritme, tinggi rendah, jarak, posisi suara dan lain sebagainya. Dengan adanya kemampuan ini makhluk hidup seperti manusia dan burung dapat memfokuskan perhatian dan memberikan respon atau tindakan terhadap bunyi yang terdengar di telinganya.

Frekuensi bunyi $f$ adalah jumlah fluktuasi bunyi yang dihitung dalam satu detik. Secara matematik dapat dituliskan dengan

$$
f=\frac{1}{T}(H z)
$$

dengan $T$ adalah periode gelombang bunyi.

Panjang gelombang $\lambda$ adalah sebuah jarak antara satuan berulang dari sebuah pola gelombang. Panjang gelombang bunyi $\lambda$ dapat dihitung secara matematik dengan membagi kecepatan bunyi pada medium tertentu dengan frekuensi bunyi $f$. Jika di udara cepat rambat gelombang bunyi adalah $343 \mathrm{~m} / \mathrm{s}$, maka panjang gelombang $\lambda$ dapat dihitung dengan

$$
\lambda=\frac{343}{f}(m)
$$

Aerodrome adalah kawasan di daratan dan/atau perairan dengan batas-batas tertentu yang hanya digunakan sebagai tempat pesawat udara mendarat dan lepas landas. Secara awam, aerodrome ini biasa disebut landasan pacu pesawat udara.

\section{METODE PENELITIAN}

Metode yang digunakan dalam penelitian ini meliputi survey lapangan dan pengambilan data secara langsung meliputi data jenis-jenis burung, data frekuensi pesawat yang beraktivitas, dan data frekuensi komunikasi burung. Data frekuensi pesawat kemudian dibandingkan dengan frekuensi komunikasi burung. Data frekuensi komunikasi burung dijadikan sebagai dasar pemilihan frekuensi sensitif pendengaran burung mengingat burung sebagai makhluk hidup akan merespon rasa sakit pada pendengaran dengan perilaku menjauhi sumber penyebab rasa sakit.

Frekuensi pesawat dan frekuensi komunikasi burung kemudian dipancarkan melalui sistem speaker pengusir burung seperti pada gambar 1 untuk kemudian diamati perilaku yang dilakukan oleh burung. Untuk keselamatan penerbangan, kegiatan ini dilakukan di area sarang burung, dan setelah didapatkan frekuensi bunyi yang sesuai maka diujikan pada area aerodrome bandar udara internasional Ahmad Yani Semarang. 


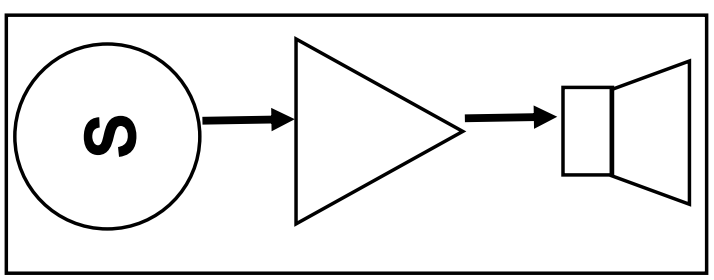

Gambar 1. Diagram sistem speaker pengusir burung

\section{HASIL DAN PEMBAHASAN}

Burung-burung yang terlihat di kawasan aerodrome bandar udara internasional Ahmad Yani Semarang dan jumlahnya dapat dilihat pada tabel 2.

Tabel 2. Jenis burung yang terlihat di sekitar aerodrome

\begin{tabular}{|c|c|c|c|}
\hline No. & $\begin{array}{l}\text { Jenis } \\
\text { burung }\end{array}$ & Nama Ilmiah & Jumlah \\
\hline 1 & $\begin{array}{l}\text { Gemak } \\
\text { tegalan }\end{array}$ & Turnix sylvatica & 2 \\
\hline 2 & $\begin{array}{l}\text { Blekok } \\
\text { sawah }\end{array}$ & Ardeola speciosa & 260 \\
\hline 3 & $\begin{array}{c}\text { Kuntul } \\
\text { kecil }\end{array}$ & Egretta garzetta & 4 \\
\hline 4 & $\begin{array}{l}\text { Kuntul } \\
\text { besar }\end{array}$ & Ardea alba & 1 \\
\hline 5 & $\begin{array}{l}\text { Kuntul } \\
\text { kerbau }\end{array}$ & Bubulcus ibis & 38 \\
\hline 6 & $\begin{array}{l}\text { Cangak } \\
\text { Merah }\end{array}$ & Ardea purpurea & 4 \\
\hline 7 & $\begin{array}{c}\text { Cangak } \\
\text { abu }\end{array}$ & Ardea cinerea & 4 \\
\hline 8 & $\begin{array}{l}\text { Trinil } \\
\text { Pantai }\end{array}$ & Actitis hypoleucos & 6 \\
\hline 9 & $\begin{array}{l}\text { Cerek } \\
\text { jawa }\end{array}$ & $\begin{array}{l}\text { Charadrius } \\
\text { javanicus }\end{array}$ & 2 \\
\hline 10 & $\begin{array}{c}\text { Cerek } \\
\text { Kernyut }\end{array}$ & Pluvialis fulva & 4 \\
\hline 11 & $\begin{array}{c}\text { Kokokan } \\
\text { laut }\end{array}$ & Butorides striata & 2 \\
\hline 12 & $\begin{array}{c}\text { Kareo } \\
\text { padi }\end{array}$ & $\begin{array}{l}\text { Amaurornis } \\
\text { phoenicurus }\end{array}$ & 1 \\
\hline 13 & $\begin{array}{l}\text { Alap-alap } \\
\text { sapi }\end{array}$ & Falco moluccensis & 1 \\
\hline 14 & $\begin{array}{l}\text { Kekep } \\
\text { Babi }\end{array}$ & $\begin{array}{c}\text { Artamus } \\
\text { leucorynchus }\end{array}$ & 6 \\
\hline 15 & $\begin{array}{c}\text { Kapinis } \\
\text { laut }\end{array}$ & Apus pacificus & 2 \\
\hline 16 & $\begin{array}{l}\text { Walet } \\
\text { sarang } \\
\text { putih }\end{array}$ & $\begin{array}{l}\text { Collocalia } \\
\text { fuciphagus }\end{array}$ & 5 \\
\hline
\end{tabular}

\begin{tabular}{|c|c|c|c|}
\hline No. & $\begin{array}{c}\text { Jenis } \\
\text { burung }\end{array}$ & Nama IImiah & Jumlah \\
\hline 17 & $\begin{array}{l}\text { Walet } \\
\text { sapi }\end{array}$ & $\begin{array}{l}\text { Collocalia } \\
\text { esculenta }\end{array}$ & 5 \\
\hline 18 & $\begin{array}{l}\text { Layang- } \\
\text { layang } \\
\text { api }\end{array}$ & Hirundo rustica & 10 \\
\hline 19 & $\begin{array}{l}\text { Tekukur } \\
\text { Biasa }\end{array}$ & $\begin{array}{l}\text { Streptopelia } \\
\text { chinensis }\end{array}$ & 80 \\
\hline 20 & $\begin{array}{l}\text { Perkutut } \\
\text { jawa }\end{array}$ & Geopelia striata & 7 \\
\hline 21 & $\begin{array}{l}\text { Kirik-kirik } \\
\text { senja }\end{array}$ & $\begin{array}{c}\text { Merops } \\
\text { leschenaulti }\end{array}$ & 2 \\
\hline 22 & $\begin{array}{c}\text { Remetuk } \\
\text { laut }\end{array}$ & $\begin{array}{l}\text { Gerygone } \\
\text { sulphurea }\end{array}$ & 1 \\
\hline 23 & $\begin{array}{l}\text { Bentet } \\
\text { kelabu }\end{array}$ & Lanius sach & 4 \\
\hline 24 & $\begin{array}{l}\text { Cucak } \\
\text { kutilang }\end{array}$ & $\begin{array}{c}\text { Pycnonotus } \\
\text { aurigaster }\end{array}$ & 9 \\
\hline 25 & $\begin{array}{l}\text { Cabak } \\
\text { maling }\end{array}$ & $\begin{array}{l}\text { Caprimulgus } \\
\text { macrurus }\end{array}$ & 2 \\
\hline 26 & $\begin{array}{l}\text { Apung } \\
\text { tanah }\end{array}$ & $\begin{array}{c}\text { Anthus } \\
\text { novaeseelandiae }\end{array}$ & 5 \\
\hline 27 & $\begin{array}{l}\text { Bondol } \\
\text { haji }\end{array}$ & Lonchura maja & 70 \\
\hline 28 & $\begin{array}{l}\text { Burung } \\
\text { gereja }\end{array}$ & Passer montanus & 56 \\
\hline
\end{tabular}

Dari tabel 2 diketahui bahwa burungburung yang banyak berada di sekitar aerodrome adalah Blekok Sawah (Ardeola speciose). Burung Blekok Sawah atau Javan Pond-heron merupakan jenis burung dari famili Ardeidae. Burung ini berukuran sekitar $45 \mathrm{~cm}$, memakan ikan kecil, vertebrata kecil seperti kodok dan katak, serta invertebrata kecil seperti cacing, crustacea, atau serangga. Blekok sawah merupakan burung dataran rendah, hidup di sekitar habitat sawah, atau daerah lain yang berair. Terkadang di mangrove, rawa, kolam, rumput tergenang, dan pinggiran sungai (Tamam, MB. 2016).

Kondisi area sekitar aerodrome bandar udara internasional Ahmad Yani Semarang secara fisik menarik perhatian burung Blekok Sawah. Beberapa tempat terlihat ada genangan air di antara rumput. Vertebrata kecil dan invertebrata kecil yang menjadi makanan burung Blekok sawah banyak dijumpai di selasela rumput. Secara geografis, letak bandar udara internasional Ahmad Yani Semarang berada di dekat pesisir utara pulau Jawa. Secara fisik dan geografis, area aerodrome bandar udara internasional Ahmad Yani Semarang merupakan tempat yang disukai burung Blekok sawah untuk beraktifitas. 


\begin{abstract}
Ukuran burung Blekok sawah yaitu sekitar $45 \mathrm{~cm}$ atau hampir setengah meter, dapat dikategorikan besar dalam konteks bird strike. Sehingga pada saat survey mengukur frekuensi komunikasi burung, maka burung Blekok sawah menjadi salah satu fokus penting. Pencarian area sarang burung Blekok sawah dilakukan pada siang hari dengan mengunjungi daerah mangrove sekitar bandar udara internasional Ahmad Yani Semarang. Sarang burung Blekok sawah dapat dikenali dengan mengamati anak-anak burung Blekok sawah yang beraktifitas di dalam sarang burung maupun di sekitarannya. Pada senja hari, dilakukan perekaman frekuensi burung-burung yang bersiap-siap beristirahat di sarangnya. Burung Blekok sawah bersarang dalam koloni yang sama dengan burung Kuntul kerbau, Kuntul kecil, dan Kuntul besar. Frekuensi bunyi beberapa burung dari hasil survey di area sarang burung tersaji pada tabel 3 .
\end{abstract}

Tabel 3. Frekuensi bunyi yang dihasilkan burung

\begin{tabular}{cccc} 
No & $\begin{array}{c}\text { Nama } \\
\text { Burung }\end{array}$ & Frekuensi & $\begin{array}{c}\text { Tingkat } \\
\text { Tekanan } \\
\text { Bunyi } \\
\text { (SPL) }\end{array}$ \\
\hline 1 & $\begin{array}{c}\text { Kuntul } \\
\text { kerbau }\end{array}$ & $2 \sim 5 \mathrm{kHz}$ & $40 \mathrm{~dB}$ \\
2 & $\begin{array}{c}\text { Blekok } \\
\text { sawah } \\
\text { Cangak } \\
\text { merah }\end{array}$ & $\begin{array}{c}0,8 \sim 2 \\
\mathrm{kHz}\end{array}$ & $38 \mathrm{~dB}$ \\
& $\begin{array}{c}\mathrm{kHz} \\
\text { Kowak } \\
\text { malam } \\
\text { kelabu }\end{array}$ & $1,6 \mathrm{kHz}$ & $39 \mathrm{~dB}$ \\
& & $39 \mathrm{~dB}$ \\
\hline
\end{tabular}

Secara umum terdapat empat jenis pesawat terbang yang beroperasi di bandar udara internasional Ahmad Yani Semarang, yaitu pesawat jenis Boeing 737, Airbus 320, Bombardier CRJ 1000 dan pesawat jenis Propeller (ATR). Karakteristik pesawat-pesawat tersebut pada saat lepas landas maupun mendarat secara berturut-turut dapat dilihat pada gambar 2 sampai dengan 5 .

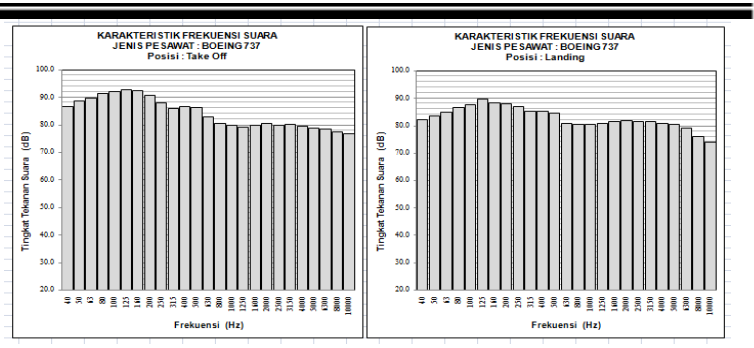

Gambar 2. Karakteristik Boeing 737

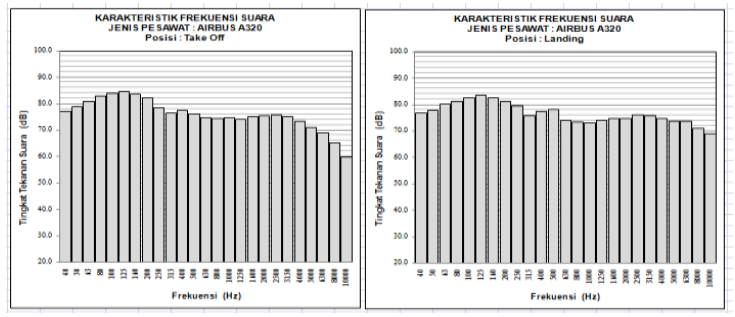

Gambar 3. Karakteristik Airbus A320

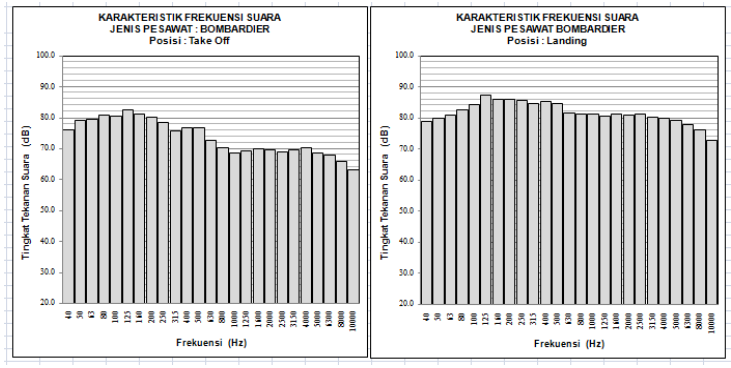

Gambar 4. Karakteristik Bombardier CRJ 1000

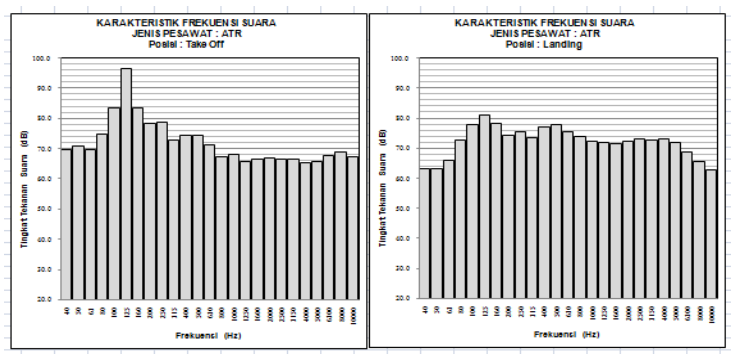

Gambar 5. Karakteristik Propeller (ATR)

Secara umum karakteristik deru pesawat terbang saat lepas landas maupun mendarat di bandar udara internasional Ahmad Yani Semarang jika dibandingkan dengan frekuensi burung dapat dilihat pada gambar 6 . 


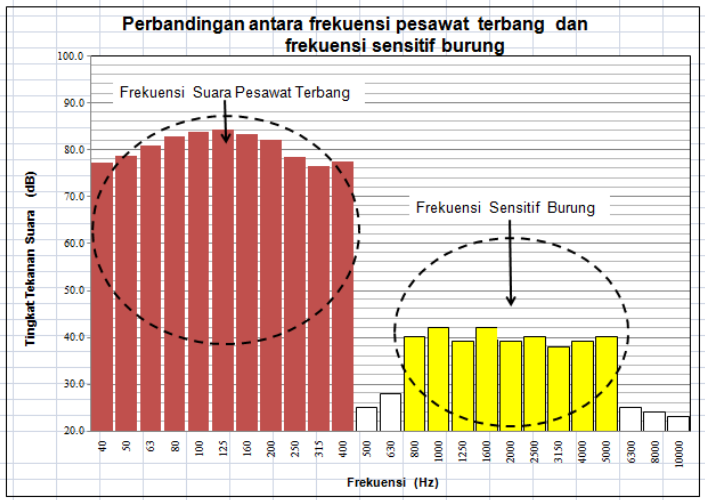

Gambar 6. Frekuensi dan tingkat tekanan bunyi pesawat dan burung.

Dari gambar 6 terlihat bahwa frekuensi burung tidak ada satu pun yang berhimpitan dengan frekuensi pesawat terbang. Oleh sebab itu, berdasarkan pengamatan di lapangan burung-burung yang ada di kawasan aerodrome bandar udara internasional Ahmad Yani Semarang tidak akan terbang menjauh ketika mereka mendengar suara pesawat, walaupun deru pesawat terbang tersebut menghasilkan tingkat tekanan bunyi yang sangat tinggi. Ini terjadi karena pendengaran burung kurang peka pada daerah frekuensi rendah. Burung-burung yang terlihat memberikan respon adalah kawanan burung gereja, yang berpindah sekitar 5 sampai 10 meter dari tempatnya semula, terutama terjadi pada saat terasa pergerakan aliran udara saat pesawat melintas.

Guna mendapatkan frekuensi mengusir burung yang tepat, maka dilakukan dua percobaan mengusir burung. Pertama dilakukan pada senja hari di area sarang burung tempat burung beristirahat setelah seharian beraktifitas. Kedua dilakukan pada pagi menjelang siang hari di area sekitar aerodrome bandar udara internasional Ahmad Yani Semarang tempat burung melakukan aktifitasnya.

Pada percobaan pertama, speaker diletakkan pada jarak sekitar 4 meter dan langsung berhadapan dengan pepohonan tempat burung bersarang. Frekuensi yang diatur pada sound generator didasarkan pada frekuensi komunikasi burung, diatur automatic frequency sweeping secara berulang mulai dari frekuensi $800 \mathrm{~Hz}$ sampai dengan frekuensi 5 $\mathrm{kHz}$ dengan durasi sweeping 2 detik. Sound amplifier diatur sehingga keluaran speaker pada jarak 1 meter sekitar $85 \mathrm{~dB}$. Tingkat tekanan bunyi $85 \mathrm{~dB}$ pada jarak 1 meter di depan speaker dipilih dengan menganalogikan batas sakit pendengaran burung adalah sama dengan manusia.
Ketika speaker mengeluarkan sinyal pada frekuensi-frekuensi tersebut, terjadi kepanikan di sarang burung dan burung-burung terbang menjauhi sumber bunyi. Beberapa burung terlihat kembali ke sarangnya setelah terbang beberapa saat menjauhi bunyi yang dihasilkan speaker. Burung-burung yang terbang kembali ke sarang terlihat mengalami gangguan keseimbangan yang diidentifikasi dari ketidaktepatan mendarat. Jumlah burung yang terbang kembali ke sarang jauh lebih sedikit bila dibandingkan dengan jumlah burung yang tetap terbang dan tidak kembali ke sarangnya. Burung yang kembali ke sarang diduga induk dari anak-anak burung yang belum dapat terbang sehingga secara naluri burung-burung tersebut kembali ke sarang untuk menyelamatkan anak-anaknya.

Pada pengamatan di hari berikutnya setelah dilakukan percobaan pertama, kegiatan burung di area sarang burung berkurang sangat banyak bila dibandingkan dengan sebelum dilakukan percobaan. Ini menunjukkan jumlah burung yang terbang meninggalkan sarang dan tidak kembali jauh lebih banyak daripada burung yang terbang kembali ke sarang.

Dari perilaku burung-burung pada saat percobaan pertama, maka frekuensi bunyi dan tingkat tekanan bunyi pada percobaan pertama menjadi dasar penentuan frekuensi bunyi dan tingkat tekanan bunyi percobaan kedua.

Pada percobaan kedua, penempatan speaker mengindahkan perilaku burung-burung pada saat terbang menjauhi speaker di percobaan pertama. Ini dilakukan untuk mencegah burung terbang mengarah ke dekat landasan pesawat atau bahkan ke landasan pesawat yang dapat membahayakan kegiatan lepas landas maupun mendaratnya pesawat terbang. Signal generator diatur automatic frequency sweeping secara berulang mulai dari frekuensi $800 \mathrm{~Hz}$ sampai dengan frekuensi 5 $\mathrm{kHz}$ dengan durasi sweeping 2 detik lebih lama dari percobaan pertama. Sound amplifier diatur sehingga keluaran speaker pada jarak 1 meter sekitar $85 \mathrm{~dB}$. Speaker diletakkan secara perlahan mendekati sekawanan burung yang sedang beraktifitas di sekitar area aerodrome untuk menghindari terbangnya burung bukan karena bunyi keluaran speaker namun karena aktifitas gerakan manusia yang bisa jadi terdeteksi oleh kawanan burung tersebut.

Ketika speaker mengeluarkan sinyal pada frekuensi-frekuensi yang diatur pada signal generator, burung-burung terlihat terbang menjauhi speaker, arah menjauhi landasan pacu bandara seperti yang diharapkan pada saat pemilihan penempatan 
dan arah speaker. Beberapa burung terlihat kembali mendarat pada jarak di luar jangkauan speaker namun tidak kembali ke posisi semula. Posisi pendaratan burung ini menjauhi landasan pacu. Burung-burung yang mendarat kembali ini terlihat mengalami gangguan keseimbangan pula.

Mendaratnya kembali burung-burung ini menginidikasikan bahwa tingkat tekanan bunyi yang dihasilkan speaker bila diukur di tempat pendaratan burung tidak lagi menyakiti pendengaran burung atau dengan kata lain dapat diterima oleh telinga burung. Jarak antara posisi awal burung dengan posisi mendarat burung dapat digunakan sebagai asumsi perhitungan untuk mengetahui jumlah efektif speaker untuk ditempatkan pada area sekitar aerodrome. Jarak ini juga dapat digunakan sebagai acuan penentuan spesifikasi speaker jika metode akustik ini dapat diterima sebagai cara mengendalikan gangguan burung di bandar udara.

\section{KESIMPULAN}

Kesimpulan yang dapat diambil dari penelitian ini adalah frekuensi bunyi yang efektif untuk mengusir burung-burung di kawasan aerodrome bandar udara internasional Ahmad Yani Semarang adalah sama dengan frekuensi yang dikeluarkan oleh burung-burung itu sendiri, yaitu dari $800 \mathrm{~Hz}$ hingga $5 \mathrm{kHz}$. Tingkat tekanan bunyi efektif yang dihasilkan speaker sebesar $85 \mathrm{~dB}$ memperlihatkan respon burung berupa terbang menjauh. Tingkat tekanan bunyi sebesar $85 \mathrm{~dB}$ ini dapat dikatakan sebagai ambang batas sakit pendengaran burung.

\section{UCAPAN TERIMA KASIH}

Terima kasih diucapkan sebesar-besarnya pada PT. Angkasa Pura I dan Bandar Udara Internasional Ahmad Yani Semarang atas kepercayaannya sehingga kegiatan Kajian Bird Strike di Bandara Ahmad Yani Semarang dapat dilaksanakan dengan baik. Terima kasih disampaikan pula kepada Laboratorium Standard Nasional Satuan Ukuran Akustik \& Vibrasi Badan Standardisasi Nasional (dahulu Subbidang Metrologi Akustik \& Vibrasi Pusat Penelitian Metrologi LIPI), dan pada tim pelaksana kegiatan Kajian Bird Strike di Bandara Ahmad Yani Semarang yaitu Bapak Achmad Suandi, Bapak Rukmana, dan Bapak Ahnan (alm.).

\section{PERNYATAAN KONTRIBUSI}

Penulis manuskrip ini menyatakan bahwa kedua penulis merupakan kontributor utama dalam penulisan dan penelitian.

\section{DAFTAR PUSTAKA}

Bishop, J. (2003). Review of international research literature regarding the effectiveness of auditory bird scaring techniques and potential alternatives. https://pdfs.semanticscholar.org/52d1/ 7a806a7156c45b3f50bf7ea8eb7b918ac 4ab.pdf

Cardoso S.H. (2001) Bird Control and Reduction Committees in the South American Region. ICAO-ACI/LAC Seminar on Bird Hazards, Environmental Protection and Land Use at Airports for the NAM/CAR/SAM (Americas) Regions. Miami, USA.

Direktur Jenderal Perhubungan Udara. (2011). Peraturan Direktur Jenderal Perhubungan Udara No. KP.468 tahun 2011 tentang Prosedur Pelaporan Serangan Burung di Bandar Udara dan Sekitarnya.

Hedayati R., Sadighi M. (2015) Bird Strike 1st Edition. An Experimental, Theoretical and Numerical Investigation. Woodhead Publishing.

Husein A. Akil. (2003). Metode Akustik untuk Menghalau Jenis Burung yang Terdapat di Sekitar Landasan Pacu Bandara Soekarno Hatta, Prosiding Seminar Nasional Akustik dan Teknik Tata Suara.

Martono A. (2007) Gangguan Burung di Bandara dan Sekitarnya. Bahan Paparan di Hadapan Civitas Akademika Fakultas Kedokteran Hewan Universitas Airlangga.

Matyjasiak, Piotr. (2008). Methods of bird control at airports. Theoretical and applied aspects of modern ecology., Edition: 1, Publisher: Wydawnictwo Uniwersytetu Kardynala Stefana Wyszynskiego., Editors: J. Uchmanski, pp.171-203

Menteri Kesehatan Republik Indonesia. (2016). Peraturan Menteri Kesehatan no 70 tahun 2016 tentang standar dan 
persyaratan kesehatan lingkungan kerja industri.

Pemerintah Republik Indonesia. (2009). Undang-Undang Republik Indonesia No. 1 tahun 2009 tentang Penerbangan.

Pusat Penelitian Metrologi LIPI. (2016). Laporan Akhir Studi Kebutuhan Alat Pengusir Burung di Bandar Udara Internasional Sam Ratulangi, Manado Sulawesi Utara.
Pusat Penelitian Metrologi LIPI. (2016). Laporan Kegiatan Kajian Bird Strike di Bandara Ahmad Yani Semarang.

Tamam, MB. (2016). Klasifikasi, Nama Latin, dan Deskripsi Burung Blekok Sawah (Ardeola speciose). https://www.generasibiologi.com/2016 /11/deskripsi-burung-blekok-sawahardeola-speciosa.html 